\title{
Discrepancies between electrocardiographic and enzyme evidence of myocardial infarction
}

\author{
P. Marrott, M. P. Chopra, R. W. Portal, and Clive P. Aber \\ From the Department of Cardiology, Kingston General Hospital, Hull
}

The discrepancies between electrocardiographic and serum enzyme evidence of acute myocardial infarction were studied in 643 consecutive patients admitted to a coronary monitoring unit.

Twenty patients $(3 \%)$ died before serum enzyme studies were made, and $7(1 \%)$ before either electrocardiograms or enzymes were obtained. In 86 per cent of the remaining 616 patients the diagnosis was evident from both electrocardiographic changes and a rise in serum enzymes.

In 13 per cent of patients serial electrocardiograms were equivocal for infarction and the final diagnosis rested on the rise in the level of enzymes. The most usual electrocardiographic findings in this group were minor $S T$ depression and $T$ wave changes and/or patterns of old infarction.

In 4 patients ( $I \%$ ) serial cardiograms showed classical changes of infarction, but serum enzymes were normal. This observation is unexplained.

Taken as a group, patients with a classical electrocardiographic pattern of transmural infarction had significantly higher serum enzyme levels, a higher incidence of major arrhythmias, and a higher hospital mortality than those without.

The difficulties encountered in identification of subendocardial and subepicardial necrosis are discussed.

The diagnosis of acute myocardial infarction is confirmed in most patients by interpretation of serial electrocardiograms. In the remainder it rests on the clinical history combined with biochemical evidence of recent myocardial necrosis. The present study analyses discrepancies between electrocardiographic and enzyme evidence of myocardial infarction.

\section{Patients and methods}

The case records were examined of 643 patients admitted to the Coronary Monitoring Unit, Kingston General Hospital, Hull, between I July 1969 and 3I July I97I, with a final diagnosis of acute myocardial infarction. All the patients were admitted within 48 hours of the onset of symptoms and had histories in keeping with acute infarction.

Conventional 12-lead electrocardiograms were performed daily for the first three days and weekly thereafter. More frequent records were obtained if warranted by the clinical condition or doubt in the diagnosis. The electrocardiographic diagnosis of acute anterior and posterior myocardial infarction was based on the criteria of the World Health Organization (1959). The recom-

Received II June 1973. mendations of the European Working Party (197I) were used to define high lateral infarction and those of Perloff (1964) to define 'true' or high posterior infarction.

Where the tracings failed to show a definite pattern of acute infarction the electrocardiographic abnormalities were classified as follows:

I) Minor ST depression and $T$ wave changes only.

2) Possible subendocardial infarction: horizontal ST segment depression of at least $\mathrm{I} \mathrm{mm}$ at its origin in any of the standard or augmented unipolar limb leads or more than $2 \mathrm{~mm}$ in any of the praecordial leads. Subsequent subsidence of the $T$ wave was also necessary.

3) Possible subepicardial infarction: (a) Steep $T$ inversion of $5 \mathrm{~mm}$ or more, and/or (b) ST elevation but no subsequent $Q$ wave formation.

4) Previous myocardial infarction.

5) Bundle-branch block.

Serum aspartate aminotransferase (SGOT) and serum $\alpha$-hydroxybutyrate dehydrogenase (SHBD) were estimated daily, for at least the first 3 days, and then weekly. The first blood sample was drawn on the day of admission when this was before 15.00 hours and otherwise at 08.00 hours the next morning. SGOT was measured by a modification of the method of Babson et al. (1962). The SHBD was determined by the method of Elliott and Wilkinson 
(I96I). The upper limits of normal in our laboratory were 40 Reitman Frankel units/ml for SGOT and 260 Wroblewski units/ml for SHBD. The SGOT and SHBD levels were considered abnormal if ro and 15 per cent, respectively, above the laboratory's upper normal limit.

\section{Results}

Twenty ( $3 \%$ ) of the 643 patients had diagnostic electrocardiograms but died before serum enzyme studies could be made. A further 7 patients died before either electrocardiographic evidence of infarction was apparent or enzyme estimations could be carried out. The clinical picture in these 7 patients and the necropsy findings in 4 left no doubt that recent myocardial infarction had occurred. The remaining 616 patients formed three groups:

Group I - Positive electrocardiogram and raised enzymes

Five hundred and thirty-one $(86 \%)$ patients had classical electrocardiographic patterns of acute myocardial infarction together with a rise in serum enzymes.

\section{Group 2 - Raised enzymes with equivocal} electrocardiograms

In 81 patients $(13 \%)$ one or both serum enzymes were raised, and though the history suggested infarction serial electrocardiograms failed to show diagnostic changes. No other cause of enzyme increase was apparent. Interpretation of the cardiograms was made by three of the authors independently. Where there was disagreement, the tracings were re-examined jointly and a conclusion reached. An analysis of these records is given in Table I. The largest category (63 patients) was that in which there was minor ST depression or $T$ wave abnormalities of variable constancy, but 23 of these had records showing previous infarction. In 6 patients $(7 \%)$ a diagnosis of subendocardial infarction could be postulated and in $5(6 \%)$ changes suggestive of subepicardial infarction were observed. Four patients $(5 \%)$ had records which showed old infarction but no current changes. Five patients $(6 \%)$ had a pattern of bundle-branch block on admission to the unit, but this abnormality had been noted previously in 2 of them.

Accurate electrocardiographic interpretation in 8 patients (10\%) was complicated by possible digitalis effects and in $4(5 \%)$ by left ventricular hypertrophy.

\section{Group 3 - Positive electrocardiogram with normal enzymes}

In 4 patients $(0.7 \%)$ serial electrocardiograms showed classical changes of acute infarction but no rise of serum enzymes was detected. All these patients were admitted within 25 hours of the onset of symptoms.

TABLE I Electrocardiographic abnormalities in 8 I patients with positive serum enzymes and equivocal electrocardiograms

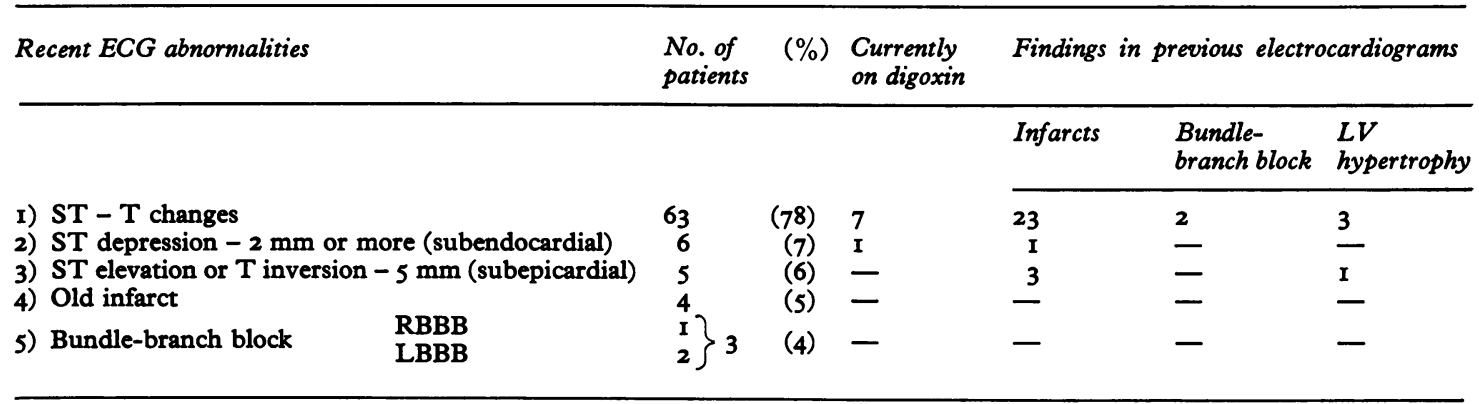

TABLE 2 Maximal SGOT and SHBD levels in roo patients with positive electrocardiograms and raised enzymes (group IA) and in 81 patients with equivocal electrocardiograms (group 2)

\begin{tabular}{lllllll}
\hline & \multicolumn{2}{l}{ Maximal SGOT units/ml } & \multicolumn{2}{l}{ Maximal SHBD units $/ m l$} \\
\hline Group & $45-146$ & $147-248$ & $>249$ & $301-900$ & $901-1500$ & $>1500$ \\
\hline IA & $50 \%$ & $29 \%$ & $21 \%$ & $43 \%$ & $34 \%$ & $23 \%$ \\
2 & $78 \%$ & $16 \%$ & $6 \%$ & $78 \%$ & $13 \%$ & $9 \%$ \\
\hline
\end{tabular}


TABLE 3 Discrepancies between SGOT and SHBD levels of patients in group $I A$ and group 2

\begin{tabular}{llll}
\hline Case No. & $\begin{array}{l}\text { Interval from } \\
\text { onset of } \\
\text { symptoms } \\
\text { to admission }(h r)\end{array}$ & $\begin{array}{l}\text { Maximum } \\
\text { SGOT }\end{array}$ & $\begin{array}{l}\text { Maximum } \\
\text { SHBD† }\end{array}$ \\
\hline
\end{tabular}

\begin{tabular}{lrll}
\hline Group IA & & & \\
I & 10 & 42 & 420 \\
2 & 48 & 49 & 230 \\
3 & 16 & 32 & 370 \\
4 & 3 & 50 & 280 \\
5 & 4 & 20 & 400 \\
6 & I & 47 & 280 \\
\hline
\end{tabular}

\begin{tabular}{lrrl}
\hline Group 2 & & & \\
I & 6 & 36 & 370 \\
2 & 12 & 48 & 270 \\
3 & 23 & 37 & 370 \\
4 & 3 & 46 & 250 \\
5 & 11 & 40 & 420 \\
6 & 3 & 21 & 450 \\
7 & 3 & 130 & 250 \\
8 & 9 & 60 & 200 \\
9 & 2 & 27 & 350 \\
\hline
\end{tabular}

* Upper limit of normal 44 units/ml.

† Upper limit of normal 300 units/ml.

\section{Comparative studies}

One hundred consecutive patients were selected from group I (positive electrocardiogram and raised enzymes) for a comparative study of maximal enzyme levels and the incidence of arrhythmias. These patients form group IA.

\section{Serum enzymes}

Table 2 compares the maximal levels of SGOT and SHBD of the 8I patients in group 2 with the 100 in group IA. These two groups were well matched in respect of the mean interval between onset of symptoms and admission (6.5 hours in group 2; $7^{\cdot 1}$ hours in group IA). Both enzyme levels were significantly higher in group IA (SGOT P < 0.0003 ; SHBD $P=0.000005$ ).

Six patients in group IA and 9 in group 2 showed a rise of only one of the two enzymes (Table 3 ). With one exception (Case 7, group 2) the observed enzyme rise was relatively small.

\section{Arrhythmias}

Major ventricular arrhythmias, complete heart block, and ventricular asystole were more frequent in group IA (Table 4).

\section{Mortality}

Of the 643 patients 90 (14\%) died in hospital. The mortality in group I was I I per cent. If the 20 patients who died early with only electrocardiographic evidence of acute myocardial infarction are included in group I, then the mortality becomes 14 per cent.

In contrast, the mortality (6 out of 81 patients) in group 2 was $7 \cdot 4$ per cent: 5 of these deaths occurred in patients with previous myocardial infarction, the terminal events being pump failure in 3 , a cerebrovascular accident in 2 , and secondary ventricular fibrillation in $\mathrm{I}$.

\section{Discussion}

In practice the classical electrocardiographic pattern of acute myocardial infarction, with evolving $Q$ waves, $S T$ elevation, and $T$ wave inversion, leaves little doubt that infarction has occurred. Increase of the commonly used serum enzymes combined with a clinical picture suggestive of infarction in the absence of liver disease, cardiac failure, pulmonary embolism, or recent trauma, is of comparable diagnostic value.

Using the defined electrocardiographic criteria, and raised SGOT and/or SHBD levels, there was concordance in the diagnosis in 531 out of the 616 $(86 \%)$ patients (group I). Woods, Laurie, and

TABLE 4 Incidence of major arrhythmias after acute myocardial infarction in 100 patients with positive electrocardiograms and raised enzymes (group IA) and in 81 patients with equivocal electrocardiograms and raised enzymes (group 2)

\begin{tabular}{|c|c|c|c|c|c|c|}
\hline & \multirow[b]{2}{*}{$\begin{array}{l}\text { Supraventricular } \\
\text { tachycardias }\end{array}$} & \multirow[b]{2}{*}{$\begin{array}{l}\text { Ventricular } \\
\text { tachycardia }\end{array}$} & \multicolumn{2}{|c|}{ Ventricular fibrillation } & \multirow[b]{2}{*}{$\begin{array}{l}\text { Complete } \\
\text { heart block }\end{array}$} & \multirow[b]{2}{*}{ Asystole } \\
\hline & & & Primary & Secondary & & \\
\hline Group IA & $\begin{array}{l}20 \\
(20 \%)\end{array}$ & $\begin{array}{l}6 \\
(6 \%)\end{array}$ & $\begin{array}{l}8 \\
(8 \%)\end{array}$ & $\begin{array}{l}6 \\
(6 \%)\end{array}$ & $\begin{array}{l}\text { 10 } \\
\text { (10\%) }\end{array}$ & $\stackrel{4}{(4 \%)}$ \\
\hline Group 2 & $\begin{array}{l}17 \\
(21 \%)\end{array}$ & $\begin{array}{l}I \\
(I \cdot 2 \%)\end{array}$ & $\begin{array}{l}2 \\
(2 \cdot 4 \%)\end{array}$ & $\begin{array}{l}4 \\
(5 \%)\end{array}$ & $\begin{array}{c}0 \\
(0 \%)\end{array}$ & $\begin{array}{l}1 \\
(1 \cdot 2 \%)\end{array}$ \\
\hline
\end{tabular}


Smith (1963) and Kibe and Nilsson (1967) obtained similar levels of diagnostic accuracy when correlating electrocardiographic evidence of acute infarction with necropsy findings.

Of patients in group 2, 13 per cent had equivocal electrocardiograms which, though abnormal, did not allow a confident diagnosis of infarction. Confirmation of recent myocardial necrosis finally rested on the observed rise in serum enzymes. Minor ST depression or $\mathrm{T}$ wave changes were the most usual findings. However, similar electrocardiographic abnormalities are frequently seen in patients with angina but without suspected recent infarction. Only 6 patients showed ST depression of more than $2 \mathrm{~mm}$, and whereas this might have been interpreted as evidence of subendocardial infarction, the criteria used (European Working Party, 197I) were arbitrary and may not provide a qualitative distinction from the lesser changes just mentioned. Though some of the patients in group 2 may have suffered transmural infarcts in areas 'silent' in respect of the conventional leads, the more likely explanation is the occurrence of patchy or subendocardial necrosis, perhaps circumferential (Levine and Ford, 1950), in which sufficient viable myocardium persists in the outer layers to prevent the development of $Q$ waves. Experimental work (Prinzmetal et al., 1954) has shown that depolarization in the subendocardial layers is more rapid than in the subepicardial layers, and contributes little to the normal QRS complex. Furthermore, Georas, Dahlquist, and Cutts (1963) reported no consistent correlation between the electrocardiographic pattern and necropsy findings in 17 patients with subendocardial infarction, and our own experience suggests that subendocardial necrosis cannot be reliably diagnosed from the electrocardiogram.

Similar difficulties arise in the definition of subepicardial infarction. Only 5 of the patients in this series fulfilled the criteria selected. The significance of giant negative $T$ waves in coronary disease has drawn previous comment (Garcia-Palmieri et al., 1956), being attributed to subepicardial injury, not necessarily constituting necrosis.

Although the enzyme rise was greater in patients with classical electrocardiographic evidence of transmural infarction, some patients with equivocal electrocardiograms (group 2) also developed a substantial enzyme rise. This is likely to imply extensive necrosis, since 5 of the 6 patients in group 2 who died had high enzyme levels, and it is known that after acute myocardial infarction the peak enzyme levels correlate well with the severity of myocardial damage, the incidence of major arrhythmias, and with prognosis (Agress et al., I955; Kibe and Nilsson, 1967; Chapman, 1971, 1972). In contrast, the relatively low incidence of major arrhythmias in group 2 should be noted. It, therefore, seems reasonable to postulate a favourable early prognosis in patients with enzyme evidence of acute necrosis, equivocal electrocardiograms, and no previous infarction.

It is not immediately obvious why 4 patients (group 3) demonstrated classical electrocardiographic abnormalities of infarction in the absence of an enzyme rise, since all these patients entered hospital within 25 hours of the onset of their acute symptoms. However, the minimal damage required to produce a classical electrocardiographic pattern of infarction is as uncertain as the lower limit of infarction detectable biochemically. In dogs, Agress et al. (1955) have shown that infarction of ro per cent (or possibly less) of the total myocardium was associated with a significant rise in SGOT.

The diagnosis of high lateral infarction presents no problem when the electrocardiogram shows $Q$ waves in aVL and V5-6, but the identification of high lateral necrosis solely on the basis of a characteristic $T$ wave change $\left(T_{1}<T_{3}, T\right.$ aVL negative, and high $\mathrm{T}$ aVF) has also been suggested (Fletcher, Morton, and Murtagh, I968). Five patients showed lateral electrocardiographic abnormalities of this kind and were placed in group 2. In our experience the recording of chest leads in higher intercostal spaces (Myers, Klein, and Stofer, I949; Fletcher et al., 1968) has not proved rewarding.

Any study on the diagnosis of acute myocardial infarction without necropsy confirmation is open to objection. In practice, however, this does not invalidate our present finding that with an appropriate clinical picture serial electrocardiograms will give the diagnosis without biochemical confirmation in 8 or 9 out of every ro patients.

Despite the limitations of enzyme assays, well displayed in the extensive survey of Goldberg and Winfield (1972), the enzyme rise has tended to become the final arbiter of necrosis, and will be appealed to where the electrocardiogram leaves the clinician in doubt. Whether or not infarction has occurred during a specific incident of ischaemic cardiac pain has important bearings on management and prognosis, for in over 2,000 patients with coronary disease admitted to the Coronary Monitoring Unit we have found only 2 exceptions to the rule that cardiac arrest does not occur in the absence of electrocardiographic or enzyme evidence of recent necrosis.

\section{References}

Agress, C. M., Jacobs, H. I., Glassner, H. F., Lederer, M. A., Clark, W. G., Wroblewski, F., Karmen, A., and LaDue, J. S. (1955). Serum transaminase levels in experimental myocardial infarction. Circulation, II, 
Babson, A. L., Shapiro, P. O., Williams, P. A. R., and Phillips, G. E. (1962). The use of a diazonium salt for the determination of glutamic-oxalacetic transaminase in serum. Clinica Chimica Acta, 7, 199.

Chapman, B. L. (197I). Correlation of mortality rate and serum enzymes in myocardial infarction. British Heart fournal, 33, 643.

Chapman, B. L. (1972). Relation of cardiac complications to SGOT level in acute myocardial infarction. British Heart fournal, 34, 890.

Elliott, B. A., and Wilkinson, J. H. (196I). Serum $\alpha$-hydroxybutyric dehydrogenase in myocardial infarction and in liver disease. Lancet, 1, 698.

European Working Party (1971). Streptokinase in recent myocardial infarction: a controlled multicentre trial. British Medical fournal, 3, 325.

Fletcher, E., Morton, P., and Murtagh, G. (1968). Electrocardiographic triad of high lateral infarction (abstract). British Heart fournal, 30, 870.

Garcia-Palmieri, M. R., Marchand, E. J., Diaz-Rivera, R. S., Santiago-Stevenson, D., and Rodriguez, H. F. (1956). The significance of giant negative $\mathrm{T}$ waves in coronary artery disease. Report of 5 cases. American Heart fournal, 52, 521 .

Georas, C. S., Dahlquist, E., and Cutts, F. B. (1963). Subendocardial infarction. Archives of Internal Medicine, III, 488.

Goldberg, D. M., and Winfield, D. A. (1972). Diagnostic accuracy of serum enzyme assays for myocardial infarction in a general hospital population. British Heart fournal, 34, 597 .
Kibe, O., and Nilsson, N. J. (1967). Observations on the diagnostic and prognostic value of some enzyme tests in myocardial infarction. Acta Medica Scandinavica, 182, 597.

Levine, H. D., and Ford, R. V. (1950). Subendocardial infarction: report of six cases and critical survey of the literature. Circulation, I, 246.

Myers, G. B., Klein, H. A., and Stofer, B. E. (1949). Correlation of electrocardiographic and pathologic findings in lateral infarction. American Heart fournal, 37, 374.

Perloff, J. K. (1964). The recognition of strictly posterior myocardial infarction by conventional scalar electrocardiography. Circulation, 30, 706.

Prinzmetal, M., Shaw, C.McK., Maxwell, M. H., Flamm, E. J., Goldman, A., Kimura, N., Rakita, L., Borduas, J. L., Rothman, S., and Kennamer, R. (1954). Studies on the mechanism of ventricular activity. VI. The depolarisation complex in pure subendocardial infarction; role of subendocardial region in the normal electrocardiogram. American fournal of Medicine, 16, 469.

Woods, J. D., Laurie, W., and Smith, W. G. (1963). The reliability of the electrocardiogram in myocardial infarction. Lancet, 2, 265.

World Heatlh Organization (1959). Hypertension and coronary heart disease: classification and criteria for epidemiological studies. First report of the expert committee on cardiovascular diseases and hypertension. World Health Organization. Technical Report Series, No. 168.

Requests for reprints to Dr. Clive P. Aber, Cardiac Department, Kingston General Hospital, Hull $\mathrm{HU}_{3}$ IUR. 